\section{Consumer preference and acceptance of two Colombian sweet milks: results of a consumer survey}

\section{Preferencia y aceptación de dos dulces de leche típicos colombianos: resultados de una encuesta a consumidores}

\author{
Juan Sebastián Ramírez-Navas*; Gina Callejas**; Claudia Quiceno**; Yonatan Valencia** \\ *Chemical Engineer, PhD in Food Engineering, Professor. GIEMA, Universidad Santiago \\ de Cali - GIPAB, Universidad del Valle, C.P. 25360, Cali, Colombia. E-mail address: juan. \\ ramirez06@usc.edu.co (J.S. Ramírez-Navas). \\ **Chemical, GIEMA, Chemistry Program, Universidad Santiago de Cali.
}

\begin{abstract}
The degree of sensory preference and acceptance of two typical Colombian sweet milk products (Arequipe and Manjar Blanco) were evaluated. Two kinds of tests - preference and acceptance (Seven-point Hedonic Test) were applied. The judging panel consisted of 76 untrained consumers from Cali. The analyses of the data were done using two statistical tests (Friedman and Wilcoxon). We found that flavor was the sensory parameter that obtained the highest ranking and consumers preferred Arequipe more than Manjar Blanco.
\end{abstract}

Keywords: sensory analysis, consumer-oriented tests, manjar blanco, arequipe, Friedman Test, Wilcoxon Test.

\section{Resumen}

Se evaluó el grado de preferencia y aceptación sensorial de dos dulces de leche típicos colombianos (arequipe y manjar blanco). Se aplicaron dos tipos de pruebas, una de preferencia y una de aceptación (prueba hedónica de siete puntos). El jurado estuvo conformado por 76 consumidores no entrenados de Cali. El análisis de los datos se realizó utilizando dos pruebas estadísticas (Friedman y Wilcoxon). Se encontró que el sabor era el parámetro sensorial que obtuvo la clasificación más alta y que los consumidores prefirieron el arequipe más que el manjar blanco.

Palabras clave: Análisis sensorial, Pruebas orientadas al consumidor, Manjar Blanco, Arequipe, Prueba de Friedman, Prueba de Wilcoxon.
Recibido: 19/02/2015

Revisado: 11/05/2015

Aceptado: 10/12/2015

Correspondencia de autor:

juan.ramirez06@usc.edu. co

(C) 2015 Universidad $\mathrm{La}$ Gran Colombia. Este es un artículo de acceso abierto, distribuido bajo los términos de la licencia Creative Commons Attribution License, que permite el uso ilimitado, distribución y reproducción en cualquier medio, siempre que el autor original y la fuente se acrediten.

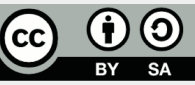

Cómo citar:

Ramirez-Navas, J.S; Callejas, L., Quiceno, C., Valencia, Y. (2015) Consumer preference and acceptance of two Colombian sweet milks: results of a consumer survey.UGCiencia 21 , 9-15. 


\section{Introduction}

Colombia produces different kinds of sweet milk such as Arequipe (caramel spread), Manjar Blanco (blancmange) and Panelitas de Leche (blancmange's brick). These dairy products are prepared from milk that is sweetened and concentrated by evaporation.

The Colombian technical standard (NTC-3757, 2008) defines: Arequipe as "The sanitized product made by the thermal concentration of a mixture involving milk, sucrose or other sweeteners and additives allowed by the national legislation in force". Manjar Blanco as "The sanitized product made by the thermal concentration of a mixture involving milk, sucrose or other sweeteners and additives allowed by the national legislation in force, with rice flour or starches added".

Neira Bermúdez and López Torres (2010) described how to make Arequipe and Novoa and Ramírez-Navas (2012b) described the Manjar Blanco manufacturing process. The preparations of these products are similar. Whole milk is neutralized with sodium bicarbonate, to prevent protein coagulation. The transformation that occurs during the preparation is caused by a combination of two common browning reactions called caramelization and the Maillard reaction. For Arequipe sucrose and glucose are added. For Manjar Blanco sucrose and starch are added. Manjar Blanco from Cauca Valley is prepared with rice flour or maize starch. The whole milk is heated at atmospheric pressure until $65^{\circ} \mathrm{Bx}$ for Arequipe or $75^{\circ} \mathrm{Bx}$ for Manjar Blanco. No enzymatic browning occurs during evaporation. For flavoring vanilla or coffee extracts, raisins or other products are sometimes added. These products are packed at $60^{\circ} \mathrm{C}$ and covered at $30^{\circ} \mathrm{C}$. Figure 1 shows the whole process. The typical compositions of Arequipe and Manjar blanco are exhibited in Table 1.

Figure 1. Steps to manufacture milk sweets

Reception of whole milk

(Milk acidity: 0.14 to $0.16 \%$ L.A.)

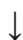

\section{Filtration}

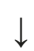

Neutralization
Sodium bicarbonate $(1 \%)$ is added.

(Milk acidity: 0.12\%. Constant stirring)

\section{$\downarrow$}

\section{Formulation and Mixture}

Arequipe: sucrose and glucose are added

Manjar blanco: sucrose and flour are added

(Continuous stirring)

$$
\downarrow
$$

\section{Preconcentration}

The mixture is heated with constant stirring at atmospheric pressure until the right solid form.

(Arequipe concentration: $65{ }^{\circ} \mathrm{Bx}$; Manjar blanco concentration: $75^{\circ} \mathrm{Bx}$.

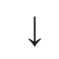

\section{Cooling}

The mixture is continuously stirred to avoid clumping

(Temperature: $60^{\circ} \mathrm{C}$ )

$$
\downarrow
$$

Packing

Filling jars. Wait to quenching and to cover jars.

(Temperature: $60^{\circ} \mathrm{C}$. To cover: $25-30^{\circ} \mathrm{C}$ )

$\downarrow$

\section{Storage}

(Temperature: $10^{\circ} \mathrm{C}-30^{\circ} \mathrm{C}$ ) 
Table 1. Typical composition of two Colombian milk sweets

\begin{tabular}{lcc}
\hline \multicolumn{1}{c}{ Composition } & Arequipe & Manjar Blanco \\
\hline Dry matter (\% wt/wt, min) & 70 & 65 \\
Total solids-not-fat $(\% \mathrm{wt} / \mathrm{wt}, \mathrm{min})$ & 17 & 16 \\
Fat $(\% \mathrm{wt} / \mathrm{wt}, \mathrm{min})$ & 7 & 6,5 \\
Ash $(\% \mathrm{wt} / \mathrm{wt}, \mathrm{max})$ & 2 & 2 \\
Starches $(\% \mathrm{wt} / \mathrm{wt}, \max )$ & -- & 4 \\
Sugar $\left({ }^{\circ} \mathrm{Bx}\right)$ & $60-67$ & $70-75$ \\
\hline
\end{tabular}

Each Colombian region has different kinds of milk sweets. Manjar Blanco is a typical product from Valle del Cauca and Arequipe from Cundinamarca. However, in the last years the consumption of Arequipe has increased, displacing typical products from other regions. The purpose of this study was to find the level of consumer acceptance and preference for Arequipe and Manjar Blanco in Cali (Capital of Cauca Valley).

\section{Materials and methods}

Samples

Representative samples were bought at a local wellknown supermarket. (Novoa \& Ramírez-Navas, 2012a; Pinilla Serrano, 2007). One kilogram of Arequipe and of Manjar Blanco was enough for this study. The date of production reported on the sample container was less than 20 days. Arequipe was made in Cundinamarca and Manjar Blanco in Valle del Cauca. These samples must meet the applicable legal Colombian regulation demanded for the manufacture and commercialization of food (NTC-3757, 2008).

\section{Physicochemical analysis}

The physicochemical properties determined were $\mathrm{pH}$, ${ }^{\circ} \mathrm{Bx}$, and water activity. The $\mathrm{pH}$ was measured using a $\mathrm{pH}$ meter Accumet with a combination $\mathrm{pH} / \mathrm{ATC}$ electrode. The sugar content was quantitatively determined based on the soluble solid content (SSC). The SSC of Arequipe and Manjar Blanco were measured using a portable refractometer (ATC model FG-109, 0-90\%) with an accuracy of $0.2{ }^{\circ} \mathrm{Bx}$ at a reference temperature. Water activity $\left(\mathrm{a}_{\mathrm{w}}\right)$ was measured with a dew-point hygrometer (Decagon, AquaLab 4TE, USA) with an accuracy of 0.0001 .

\section{Measurement of color}

Color was measured from 400 to $780 \mathrm{~nm}$, utilizing a spectrocolorimeter (Color flex ${ }^{\circledR}$ - Hunter Lab, USA). L*, $a^{*}$ and $b^{*}$ of Arequipe and Manjar Blanco were determined. $\mathrm{L}^{*}$ is the luminance or lightness component, which ranges from 0 (dark) to 100 (light), and the parameters a* (from green to red chromaticity, from 60 green to 60 red) and $b^{*}$ (from blue to yellow chromaticity, from 60 blue to 60 yellow) are the two chromatic components which range from -60 to 60 . The $\mathrm{L}^{*} \mathrm{a}^{*} \mathrm{~b}^{*}$ space is perceptible uniform. The $\mathrm{L}^{*} \mathrm{a}^{*} \mathrm{~b}^{*}$, or CIELab, color space is the international standard for color measurements. CIE D 65 was selected as the illuminating source (day sunlight), $10^{\circ}$ as standard observer angle, and CIE-L*a*b* color scale. Color parameters were obtained using the CIE-LAB space. The equipment was standardized utilizing a Petri dish in the port according to manufacturer instructions. The test procedure began filling a Petri dish with sufficient sample taking care not to leave air bubbles in the bottom. Color was measured three times. The Petri dish filled with sample was analyzed in the spectrocolorimeter and readings of color were taken, the sample was then rotated $120^{\circ}$. This procedure was repeated thrice and the readings were averaged (Novoa \& Ramírez-Navas, 2012a; Ramírez-Navas, Cañizares S., \& Acevedo C., 2011).

The differences in Color $(\Delta \mathrm{E})$ for Arequipe and Manjar Blanco were determined by the following equation (Ramírez-Navas \& Rodríguez de Stouvenel, 2012):

$$
\Delta E_{A, M B}=\sqrt{\left(\Delta L_{A, M B}^{*}\right)^{2}+\left(\Delta a_{A, M B}^{*}\right)^{2}+\left(b_{A, M B}^{*}\right)^{2}}
$$

Where $\Delta \mathrm{L}^{*}, \Delta \mathrm{a}^{*}, \Delta \mathrm{b}^{*}$ are color differences between values of Arequipe (A) and Manjar Blanco (MB).

\section{Sensory analysis}

Two consumer tests (preference and acceptance) were conducted according to Ramírez-Navas (2012). Preference is an expression of greater degree of liking. Acceptance is an experience characterized by a positive attitude (Hall Ellis, 1969).

Place and Personnel. The sensory evaluations of Arequipe and Manjar Blanco samples were conducted by a panel of 76 untrained consumers of both genders. The panel age ranged from 18 to 65 years old people. 
They had different occupations (students, office-workers, security guards, among others) and social class (1 to 6), living in the city. Tests were conducted at Universidad Santiago de Cali. The first group (38 consumers) tested the samples in the morning ( 9 to 10) and the second group (38 consumers) did it in the afternoon (3 to 4).

Sample Presentation. Two different samples were presented to consumers: Arequipe and Manjar Blanco, $2 \mathrm{~g}$ of each sample. Disposable plastic medium-sized spoons were used. Both samples were coded with 3-digit random numbers (A: 265, MB: 412). Care was taken that both samples had the chance to take the first place the same number of times, to avoid error due to order. Instruction to evaluate the samples was indicated in the respective format. Both samples were presented simultaneously; each participant tested each sample just one time, next drank water, and ate salt-free soda crackers as a neutralizer to avoid interferences with the following trial.

Paired-preference Test. Participants were asked which of the two coded samples they preferred. They were asked to select one, even if both samples were identical for them.

Acceptance Test: A 7-point hedonic scale was used for each descriptor with scores ranging from " 1 " indicating extreme dislike to "7" indicating an extremely high acceptance level, and " 4 " indicating indifference.

\section{Statistical analysis}

The physicochemical features of samples from two typical Colombian milk sweets: $\mathrm{pH}$, degrees Brix, water activity, and Color were analyzed by analyses of variance. Means comparisons were performed by Tukey's test. All statistical analyses were conducted at a significant level of $\mathrm{P} \leq 0.05$ with PSPP v.0.8.1, statistical software.

The statistical model used in this study was: $Y i j=\mu+F i$ $+E E$. Where Yij represents the response of consumer $j$ who receives the milk sweet product $i, \mu$ is the average degree of acceptance, Fi represents the treatment effect (type of milk sweet product), and EE is the experimental error that represents the variability among the responses of the consumers within the treatments. Sensory data were analyzed using PSPP v.0.8.1, statistical software. Friedman Test (Corder \& Foreman, 2009) and Wilcoxon Test (McCornack, 1965; Romo S, 1973) were applied. For all analyses, the significance of differences at $95 \%$ level $(\mathrm{P}<0.05)$ between averages was determined.

\section{Results}

\section{Physicochemical analysis}

Table 2 shows the average values of the physicochemical variables quantified in triplicate, for samples of the two typical Colombian milk sweets. There was statistically significant $(\mathrm{P}>0.05)$ difference in all values of $\mathrm{pH}$, ${ }^{\circ} \mathrm{Bx}$ and $\mathrm{a}_{\mathrm{w}}$. Arequipe is less acidic than Manjar Blanco. Maybe due to this, milk is neutralized with sodium bicarbonate to avoid the coagulation of casein in the manufacture of Arequipe. Manjar Blanco has more total solids, due to the addition of rice flour or maize starch during its elaboration. However, the two samples present a value of ${ }^{\circ} \mathrm{Bx}$ exceeding $65^{\circ} \mathrm{Brix}$, which agree with the recommended value of these products (NTC-3757, 2008).

Table 2. Physicochemical Analysis of two typical Colombian milk sweets

\begin{tabular}{llllllll}
\hline \multicolumn{1}{c}{ Product } & \multicolumn{1}{c}{$\mathbf{p H}$} & \multicolumn{2}{c}{${ }^{\circ} \mathbf{B x}$} & \multicolumn{2}{c}{$\mathbf{a}_{\mathbf{w}}$} \\
\hline Arequipe (A) & 6.74 & a & 67.31 & b & 0.86 & a \\
Manjar Blanco (MB) & 5.83 & b & 75.81 & a & 0.73 & b \\
\hline
\end{tabular}

a, b Different superscripts letters within same column indicate statistical differences $(P<0.05)$

Present data are mean values of three replicates.

\section{Colorimetric measurement}

The results of the CIELab analyses of two typical Colombian milk sweets are presented in Table 3. They were determined in triplicate. The color difference value is also shown. There was a statistically difference between the two samples $(\mathrm{P}>0.05)$ in $\mathrm{L}^{*}, \mathrm{a}^{*}$, and $\mathrm{b}^{*}$ values. A is darker than $\mathrm{MB}$ and with a greater tendency to have a red color. However, the MB sample presents a higher $\mathrm{b}^{*}$ value, indicating a marked tendency toward yellow. When $\Delta \mathrm{E}$ value is greater than 2.7 , the color difference between A and MB is notable (Ramírez-Navas, 2010).

Table 3. Color parameters of two typical Colombian milk sweets by CIELAB method

\begin{tabular}{lccccc}
\hline & $\mathbf{L}^{*}$ & $\mathbf{a}^{*}$ & $\mathbf{b}^{*}$ & ÄE \\
\hline Arequipe (A) & 38.62 & b & 15.51 a & 29.18 b & \\
Manjar Blanco (MB) & 44.25 & a & 13.37 b & 34.73 a & \\
\hline
\end{tabular}

a, b Different superscripts letters within same column indicate statistical differences $(P<0.05)$

Present data are mean values of three replicates 
Based upon the data collected from the tests used (Pairedpreference Test, hedonic test of 7 points) in the sensory analyses of the two types of milk sweets, the descriptive statistics of samples (mean and standard deviation) were determined and the Friedman and Wilcoxon tests applied.

Figure 2 are displayed the percentage of participants who preferred a given sample. It shows that consumers surveyed had a higher degree of preference for A samples $(61.84 \%)$ than for MB samples $(38.16 \%)$.

Figure 2. Preferential differences between Arequipe (A) and Manjar Blanco (MB)

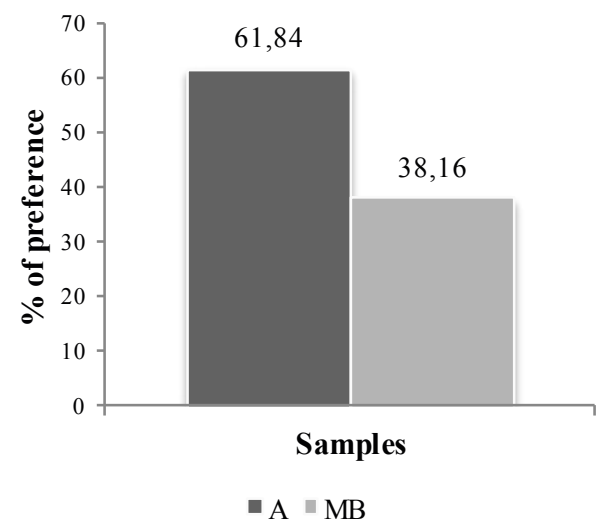

Figure 3 shows the percentage of participants who preferred one of the samples according to the age range ( 15 to 20,21 to 30,31 to 40 and 41 to 65 ). Sample A was preferred by first group (15 to20) with a $71.9 \%$, those in the second group (21 to 30 ) had a $58.6 \%$, very similar to those in the 31 to 40 age with a $57.1 \%$. The group 41 to 70 preferred MB with a $62.5 \%$.

Figure 3. Preferential differences between Arequipe (A) and Manjar Blanco (MB) according to the age ranges studied

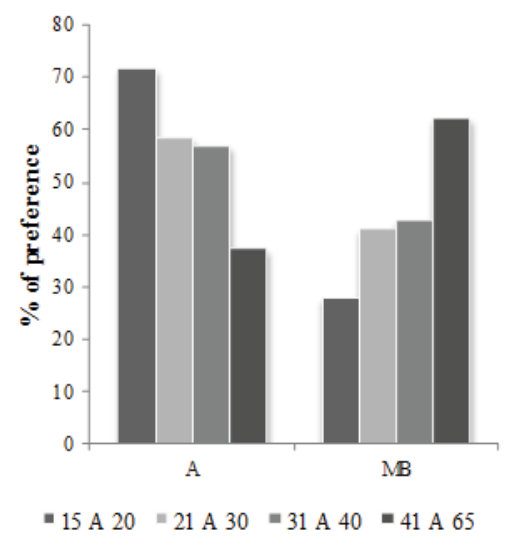

Figure 4 shows the percentage of participants, in agreement with the social stratum (1 t0 6), who chose one of the samples. First, it is observed that A sample was preferred by people in stratum 3 with a $66.7 \%$, those in stratum 4 had a $76.9 \%$ and for strata 5-6 the percentage acceptance was $62.5 \%$. On the other hand, MB sample was preferred by strata $1-2$ with a $57.9 \%$.

Figure 4. Percentage acceptance of Arequipe (A) and Manjar Blanco (MB) according to the social class

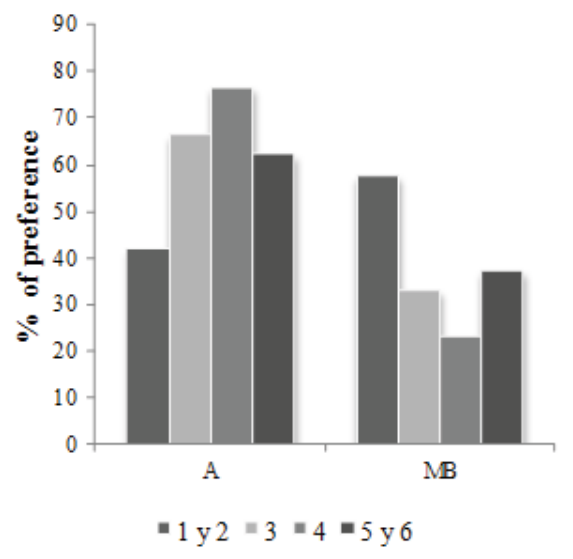

The degree of acceptance of the two tested trademarks which were subjected to sensorial evaluation in terms of smell, color, and texture by 76 consumers (at the Universidad Santiago de Cali) using hedonic scales of 7 points, synthesized in the averaged ranges determined through Friedman test. In Table 4 are shown the mean standard deviation, median, and the range of the grades assigned by the consumers.

In Table 4 it is observed that $\mathrm{A}$ got the highest rating assigned by the consumers (averaged $\mathrm{X}$ and median $\mathrm{Me}$ ) and $\mathrm{MB}$ presented higher dispersion than $\mathrm{A}$ as far as the acceptance of its sensory parameters (smell, color, flavor, and texture). The results of Friedman test shows that A obtained higher ranges in smell (1.55), color (1.66), flavor (1.65) and texture (1.71). The attributes: color $(\mathrm{p}=0,001<0.05)$, flavor $(\mathrm{p}=0.003<0.05)$ and texture $(\mathrm{p}=0.000<0.05)$ between $\mathrm{A}$ and $\mathrm{MB}$ differ significantly as the odor results $(p=0.238>0.05)$ did not differ significantly. This criterion allows determining which product presents a better color, flavor and texture according to the sensory evaluation of the consumers. What was indicated by Friedman Test is verified by the results of the Wilcoxon test, where it is observed that 
there are not significant differences between $\mathrm{A}$ and $\mathrm{MB}$ in terms of smell $(\mathrm{Z}<\mathrm{QP})$, but there exist meaningful differences $(\mathrm{Z}>\mathrm{QP})$ between the attributes color, flavor and texture.

Table 4. Statistic descriptions, Friedman test results and Wilcoxon signed-rank test for the sensory attributes smell, color, flavor and texture of two typical Colombian sweets subjected to sensorial evaluation be considered a cause of the preference showed towards this product and could be used as a marketing strategy in order to increase MB sales during other seasons of the year (Fig 4).

Acceptance Analysis. Flavor was the sensory parameter that obtained the highest ranking. This must be due to the fact that product $\mathrm{A}$ had a strong mixture of flavors: sweet, caramel and vanilla whereas in MB a milky flavor

\begin{tabular}{|c|c|c|c|c|c|c|}
\hline \multirow{3}{*}{$\begin{array}{c}\text { Brand } \\
A, X \pm s\end{array}$} & \multicolumn{6}{|c|}{ Statistical Descriptions ${ }^{1}$} \\
\hline & \multicolumn{2}{|r|}{ S mell } & \multicolumn{2}{|r|}{ Color } & Flavor & \multirow{2}{*}{$\frac{\text { Texture }}{6.13 \pm 1.075}$} \\
\hline & 5.95 & \pm 1.142 & 6.14 & $\pm 1,116$ & $6.30 \pm 1.007$ & \\
\hline $\mathrm{MB}, \mathrm{X} \pm \mathrm{s}$ & 5.68 & $\pm \quad 1.397$ & 5.50 & $\pm \quad 1,291$ & $5.70 \pm 1.255$ & $5.32 \pm 1.426$ \\
\hline $\mathrm{A}, \mathrm{Me} \pm \mathrm{R}$ & 6 & \pm 4 & 7 & \pm 3 & $7 \pm 4$ & $7 \pm 4$ \\
\hline $\mathrm{MB}, \mathrm{Me} \pm \mathrm{R}$ & 6 & \pm 6 & 6 & $\pm \quad 5$ & $6 \pm 5$ & $6 \pm 6$ \\
\hline Friedman Test & \multicolumn{6}{|c|}{ Averaged Range } \\
\hline A & & 1.553 & & 1.658 & 1.651 & 1.711 \\
\hline MB & & 1.447 & & 1.342 & 1.349 & 1.289 \\
\hline$F_{r(r)}$ & & 1.391 & & 12.000 & 8.966 & 16.000 \\
\hline $\mathrm{p}$ & & 0.238 & & 0.001 & 0.003 & 0.000 \\
\hline Wilcoxon Test & \multicolumn{6}{|c|}{ Averaged Range } \\
\hline$|\mathrm{Z}|$ & & 1.187 & & 3.379 & 3.192 & 3.508 \\
\hline $\mathrm{p}$ & & 0.235 & & 0.001 & 0.001 & 0.000 \\
\hline
\end{tabular}

* Where, A: Arequipe, MB: Manjar Blanco del Valle

1 Averaged values obtained by means of the sensory analysis of samples from two typical Colombian milk sweets (76 non-trained consumers) b QP $5 \%=2.77$

\section{Discussion}

Sensory Analysis

Preference Analysis. The results may be understood if we accept that the introduction of Arequipe in the Cauca Valley market is relatively new and consumers were accustomed to their traditional product. On the other hand, younger consumers prefer A product.

However, in terms of Price, MB is twice more expensive that A. It is important to highlight also that in December, dairy farms give milk to peasants and people belonging to low social strata and thus they prepare MB. This may was the strong one. By comparing the instrumental and sensory results, it is observed that consumers prefer the brilliant brown caramel of A instead of the cream opaque of MB. This is in agreement with Andrade P, Vélez H, Arteaga M, Díaz Q, and Sánchez S (2009), who pointed out that customers are used to mainly consume Brown caramel milk sweets. Another important attribute for the consumers was texture. Both products had a soft texture; however, A was creamy and soft on the inside while MB was sandy. For smell, consumers did not show a strong preference. 


\section{Conclusions}

The customers preferred better the characteristics of Arequipe over Manjar Blanco. The greater acceptance of Arequipe is due to its flavor, color, and texture.

\section{Acknowledgments}

The authors are grateful to Universidad Santiago de Cali and its staff for allowing conducting the study in its facilities and also to each participant in the survey. The authors thank Professor Alonso Jaramillo for their assistance with translation.

\section{References}

Andrade P, R. D., Vélez H, G. I., Arteaga M, M. R., Díaz Q, Y. S., \& Sánchez S, S. S. (2009). Efecto de la neutralización y adición de edulcorante en las propiedades fisicoquímicas, microbiológicas y sensoriales del Arequipe de leche de búfala. VITAE, 16(2), 201-209.

Corder, G. W., \& Foreman, D. I. (2009). Nonparametric statistics for non-statisticians : a step-by-step approach. Hoboken, N.J.: Wiley.

Hall Ellis, B. (1969). Acceptance and Consumer Preference Testing. Journal of dairy science, 52(6), 823-831. doi: 10.3168/jds.S00220302(69)86658-0

McCornack, R. L. (1965). Extended Tables of the Wilcoxon Matched Pair Signed Rank Statistic. Journal of the American Statistical Association, 60(311), 864-871. doi: 10.2307/2283253

Neira Bermúdez, E., \& López Torres, J. (2010). Guía técnica para la elaboración de productos lácteos (5 ed.). Bogotá: De la Mancha Impresores.

Novoa, D. F., \& Ramírez-Navas, J. S. (2012a). Caracterización colorimétrica del Manjar Blanco del Valle. Biotecnología en el Sector Agropecuario y Agroindustrial, 10(2), 54 - 60.

Novoa, D. F., \& Ramírez-Navas, J. S. (2012b). Manjar Blanco del Valle: Un dulce de leche típico colombiano. Tecnología Láctea Latinoamericana, 68, 48-52.
NTC-3757. (2008). Arequipe o dulce de leche y manjar blanco (Vol. 3757): Instituto Colombiano de Normas Técnicas y Certificación.

Pinilla Serrano, G. E. (2007). Factibilidad para la creación de una empresa productora y comercializadora de arequipe en diversas presentaciones en Floridablanca, Santander. (Tesis de Profesionel en Gestión Empresarial), Universidad Industrial de Santander, Bucaramanga, Colombia.

Ramírez-Navas, J. S. (2010). Espectrocolorimetría: caracterización de leche y quesos. Tecnología Láctea Latinoamericana, 61, 52-58.

Ramírez-Navas, J. S. (2012). Análisis sensorial: pruebas orientadas al consumidor. Revista Reciteia, 12(1), 83-102.

Ramírez-Navas, J. S., Cañizares S., J. E., \& Acevedo C., D. (2011). Criodesecación atmosférica de papa (Solanum tuberosum). Revista Facultad de Ingeniería Universidad de Antioquia, 61, 74-82.

Ramírez-Navas, J. S., \& Rodríguez de Stouvenel, A. (2012). Characterization of Colombian Quesillo Cheese by Spectrocolorimetry. Vitae, 19(2), 178-185.

Romo S, L. A. (1973). Métodos de experimentación cientifica ( $1^{\text {st }}$ ed.). Quito, Ecuador: Editorial Universitaria. 